UJBM, Vol. 8, No. 1, January - June 2009, pp 35-46

ISSN 0975-3311 | https://doi.org/10.12725/ujbm.14.5

\title{
ENVIRONMENTAL ACCOUNTING LINKAGE TO SUSTAINABLE COMPETITIVE ADVANTAGE AND CORPORATE SOCIAL RESPONSIBILITY
}

\author{
Leena James* \& Umaselvi**
}

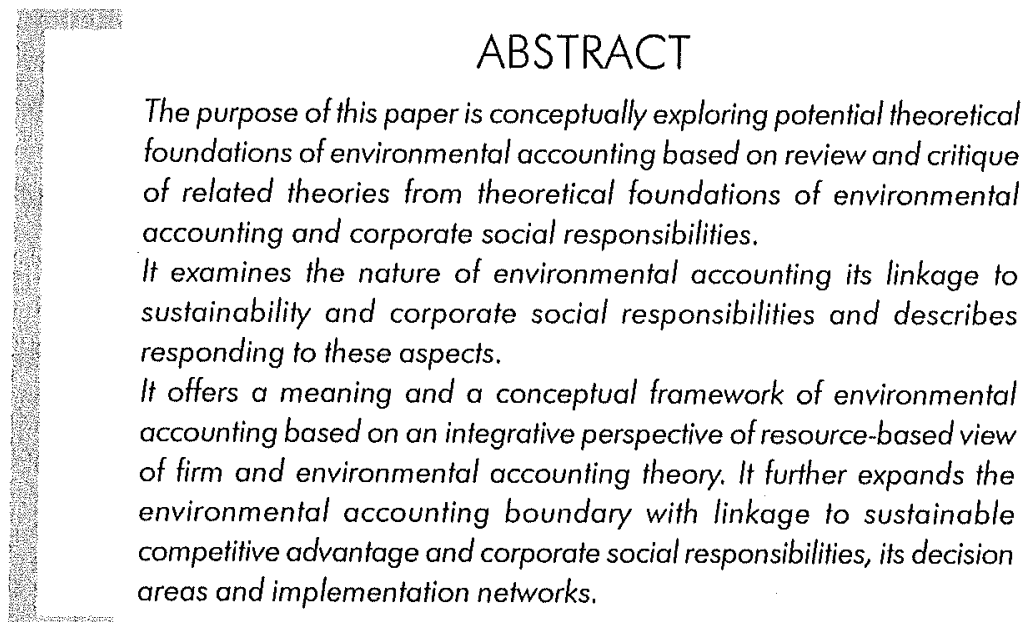

* Christ University, Bangalore-29, leena.james@christuniversity.in

**Christ University, Bangalore-29, umaselvia@yahoo.co.in 


\section{Introduction}

The topic of 'Environmental Accounting' draws growing attention in the field of business and accounting and that identifies resource use, measures and communicate the cost of a company on the national economy actual as potential impact as the environment. It aims to incorporate both economic and environmental information in the corporate.

\section{Evolution of Enviornmental Accounting}

Modern forms of Environmental and social responsibility accounting dates back to the early 1970s when some companies developed accounting programs on their own, for recording and evaluating environmental problems associated with their operations.

This concept got protected under the guise of a number of different approaches and names such as social responsibilities accounting, sustainability accounting, non-financial reporting, social and enviornmentalaccounting, and corporate social reporting, etc. There has been a steady growth is this discipline since then.

The American consultancy firm Abt Associates, is one of the most cited early examples of businesses that experimented with environmental accounting. In the 1970s the company addressed no of environmental issues and conducted a series of social reporting incorporated in to its annual reports. The social and environmental concerns addressed included "productivity, contribution to knowledge, employment security, fairness of employment opportunities, health, education and self-development, physical security, transportation, recreation and environment".(D.Blake, 1976)

One of the first countries to build environmental accounts is Norway, which began collecting data on energy sources, fisheries, forests and minerals in the 1970s to address resource scarcity. Over time, the Norwegians have expanded their accounts to include data on air pollutant emissions. Their accounts feed into a model of the national economy. 


\section{Literature Review on Definition of Environmental Accounting}

Environmental accounting is a subset of social accounting, focuses on the cost structure and environmental performance of a company. It principally describes the preparation, presentation, and communication of information related to an organization's interaction with the natural environment. Although environmental accounting is most commonly undertaken as voluntary selfreporting by companies, third-party reports by government agencies, NGOs and other bodies posit to pressure for environmental accountability.

Social accounting emphasizes the notion of corporate accountability, D.Crowther defines social accounting in this sense as "an approach to reporting a firm's activities which stresses the need for the identification of socially relevant behaviour, the determination of those to whom the company is accountable for its social performance and the development of appropriate measures and reporting techniques.".

What constitutes the "Environmental Accounting" of enterprises and other organizations is difficult to define. There is no single authoritative definition of Environmental Accounting. However, it notes that most definitions emphasize the interrelationship between, environmental and social aspects and impacts of an organization's activities.

Environmental accounting, is a concept describing the communication of social and environmental effects of a company's economic actions to particular interest groups within society and to society at large.

The common definition of "environmental accounting" is "the identification, measurement, and allocation of environmental costs, the integration of these environmental costs into business decisions, and the subsequent communication of the information to a company's stakeholders" (AICPA).

Typical environmental costs include off-site waste disposal costs, cleanup costs, litigation costs, and other related costs.

The measurement and reporting the impact of exchanges between a firm and its social environment is referred to as environmental accounting. The main object of socio-economic accounting is to internalize the social costs and benefits to determine a more relevant and exhaustive result that represent a socio-economic profit of a firm. 
According to Ramanathan (1976), environmental accounting is "the process of selecting firm level social performance variables, measures and measurement procedures, systematically developing information useful for evaluating firm's social performance and communicating such information to concerned social groups both within and outside the firm". Ralph Estes defines environmental I accounting as "the measurement and reporting, internal or external of information concerning the impact of an entity and its activities on society" (Estes, 1976).

While establishing the need of environmental accounting defined it as "the ordering, measuring and analysis of the social and economic consequences of governmental and entrepreneurial behavior" (Mobley Sybil) The National Association of Accountants Committee on Accounting for corporate social performance defined environmental accounting as "the identification, measurement, monitoring and supporting of the social and economic effects of an institution on society. It is intended for both internal managerial and external accountability purposes and is an out growth of changing values that have led society to redefine its notion of a corporation's social responsibility" (NAA Committee Report, 1976).

According to the committee on accounting for social performance of the American Accounting Association, (AAA) environmental accounting would include -

- Accounting for and evaluating of the impact of corporate social responsibility programmes.

- Human resource accounting.

- Measurement of selected social costs.

- Measuring the full impact of an entity on society.

- Accounting for public programmes essential for corporate reporting. (AAA Committee, 1975)

\section{Significance and Scope of the Study}

The concept of Environmental Accounting has received increased attention in the recent past. Many academicians and practitioners have asserted that 
a new paradigm for business is developing. That is, the one that emphasizes firm's responsibilities to multiple stakeholders in addition to the more traditional, singularly emphasized shareholder (Frooman, 1984; Etzioni, 1988; Capra, 1992; Brenner, 1993; Reef, Muralidhar and Paul, 1993; Clarkson 1995; 1998; Donaldson and Preston, 1995; Sethi, 1995; Shrivatsava, 1995; Griffin and Mahon, 1997; Mitchell et al., 1997). The model of social responsibility accounting has evolved from Bowen's (1953) early work on the social responsibility of the businessman Davis's (1973) essay on the pros and cons of corporate social responsibility to Carroll's (1979) corporate social responsibility model of economic, legal, ethical and discretionary domains to Wartick and Cochran's (1985) addition of "issues management" to Wood's (1991) seminal, multilevel, theoretical framework of the principles, processes and outcomes of Environmental Accounting

The significant of the study is argued for the following reasons. First, this paper can expand the knowledge base of environmental accounting through its review and critique on existing literature. It benefits people interested in environmental accounting theoretical research by providing a framework and understanding. The scope of social accounting thus includes but extends beyond that of traditionally reported economic effects. A firm may be engaged in social accounting when it moves beyond its financial operations and begins to measure and evaluate its other effects on society

\section{Why Environmental Accounting?}

Environmental accounting challenges conventional accounting, in particular financial accounting, for giving a narrow image of the interaction between society and organizations, and also questions the reduction of all meaningful information to final form and thus artificially constraining the subject of accounting.

Environmental accounting offers an alternative account of significant economic entities. It has the "potential to expose the tension between pursuing economic profit and the pursuit of social and environmental objectives.

The purpose of environmental accounting can be approached from two different angles, namely for management control purposes or accountability purposes. 
Social accounting for accountability purposes is designed to support and facilitate the pursuit of society's objectives.

Environmental accounting for the purpose of management control is designed to support and facilitate the achievement of an organization's own objectives

\section{Environmental Concern and Accounting -}

\section{A SUSTAINABLE APPROACH OF CORPORATE SOCIAL RESPONSIBILITY}

An organization with a superior corporate social responsibility program is able to implement and report on the social and environmental impacts of its operations.

It is the objective of this article to determine the extent to which this consciousness towards environmental sustainability has speed in to the accounting horizons of business houses.

As part of this responsibility concerned the companies have to disclose the interaction between the firm and the ecological environment. During $80 \mathrm{~s}$ and early 90 s the emphasis in the accounting literature shifted from social responsibility accounting to environmental accounting reflecting the strong interest in the latter from 1990s to date the emphasis on environmental accounting continues unabated and engages the interest of both academic and practicing accountants.

\section{Environmental Sustainability and Corporate Social Responsibility}

To protect the business interest for a sustainable future in the long-run, it is highly desirable that the resources they rely on must also be sustainable. In the recent decade, the changing environment of our planet and its possible serious consequences became a matter of discussion among the global community. With these factors as prime concern, corporate houses also included environmental protection activities and their reporting under the purview of their corporate social responsibilities policy. Many corporates across the globe are acting as responsible citizens by implementing environmental concern in their business strategy and they are also promoting green behaviour in society. Many organizations have desired, framed and changed special strategies and policies in their corporate social 
responsibilities and accounting policies for safeguarding the environment. It is generally agreed that environmental accounting will cover an organizations relationship with the natural environment, its employees, and wider ethical issues concentrating upon consumers and products, as well as local and international communities.

With regard to the environmental reporting the Global Reporting Initiative (GRI) Principles are an invaluable tool for working towards international confidence in the trustworthiness of corporate reporting. The overall aim of the GRI - based reporting is to:

- Provide a balanced and reasonable representation of an organization's sustainability performance.

- Facilities comparability.

- Address issues of concern to stakeholders.

The GRI reporting principles are the underpinnings of corporate report content, and as such are as important as the content itself. The reporting principles are:

- Transparency: Fully disclosure of the processes, procedures and assumptions in report preparation are essential to its credibility.

- Inclusiveness: The reporting organization should engage its stakeholders in preparing and enhancing the quality of reports.

- Auditability: Reported information should be recorded, complied, analyzed and disclosed in a way that enables internal auditors or external assurance providers to attest to its reliability.

- Completeness: All material information should appear in the report.

- Relevance: Reporting organizations should use the degree of importance that report users assign to particular information in determining report content.

- Sustainability Context: Reporting organizations should seek to place their performance in the broader context of ecological, social or other issues where such context adds significant meaning to the reported information. 
- Accuracy: Reports should achieve a degree of exactness and low margin of error to enable users to make decisions with a high degree of confidence.

- Neutrality: Reports should avoid bias in selection and presentation of information and provide a balanced account of performance.

- Comparability: Reports should be framed so as to facilitate comparison to earlier reports as well as to reports of comparable organisations.

- Clarity: Information should be presented in a manner that is understandable by a maximum number of users while still maintaining a suitable level of details (GRI, 2002).

The work of developing, implementing and verifying these reporting standards for corporate social and environmental responsibility will continue for many years to come, reinforcing the effort that is now being made in the quest to achieve better measurement and reporting of intangibles. However, the whole edifice of Corporate Social Responsibility and ESG analysis and valuation will rest on the adequacy and rigour of reporting standards. Further developments will entail redesign of the corporation.

A group of business and community leaders in the US have projected a vision of Corporation 2020 based on the imperative to redesign the corporation. The principles they advocate are that the purpose of the corporation is to harness private interests to serve the public interest, that fair returns to shareholders should not be at the expense of the legitimate interests of other stakeholders, that corporations should operate sustainably, and that corporations distribute wealth produced equitably among those who contribute to the creation of that wealth. Robert Hinkley offers a 28 word amendment to directors duties which states that they are to act in the interests of the company "but not at the expense of the environment, human rights, public health and safety, dignity or employees, or the welfare of communities in which the corporation operates" (Luis, 2005).

\section{Drives that Motivates Corporates}

With the awareness of environmental impact of industry operations, corporations should have a much broader mindset towards, social responsibility and its accounting. Todays business houses are no longer 
solely concerned with bottom line results and how to stay afloat is a highly competitive environment. The new breed among them also thinks of community development, poverty mitigation sustainability of earths resources such as effective use of energy and prevention of global warming where social and environmental concerns has to be accounted for.

Organizations are seen to benefit from implementing social accounting practices in a number of ways, like

- Increased information for decision-making;

- More accurate product or service costing;

- Enhanced image management and Public Relations;

- Identification of social responsibilities;

- Maintaining legitimacy.

The "process of reporting on responsible business performance to stakeholders" (i.e. environmental accounting). helps to integrate such practices into business practices, as well as identifying future risks and opportunities

\section{Decision Areas of Environmental Accounting}

There are very practical reasons for environmental accounting geared, as outstanding ambition is becoming the order of the day. Local authorities /companies are increasingly being responsible for their impact on the environment government finds them as key players to launch sustainable development programs. The moves towards strategic environmental assessment are now widely accepted through out the globe forcefully. Local authorities and companies will soon find that with out the proper accounting of environmental strategy their credibility with the funding or sharing bodies will be thinner.

When dealing with strategic policies such as residential and commercial location policy, educational provision, density issues, traffic planning, waste disposal, pollution control, energy saving, transport-energy-industry policy, green belt, urban from, rural settlement policies and economic generation strategies, the problems of complex systems arise prominently. 
To solve these tasks, the overseas countries used Network Analysis, actually provide a kit of simple tools-linkages diagrams, matrices and flow chartscapable of shaping the complexities and provides a framework for policy evaluation.

The process of analyzing connections should be tackled systematically, by linking policy areas of common environmental impacts. The following figure displays the Network Analysis of diverse environmental decision areas.

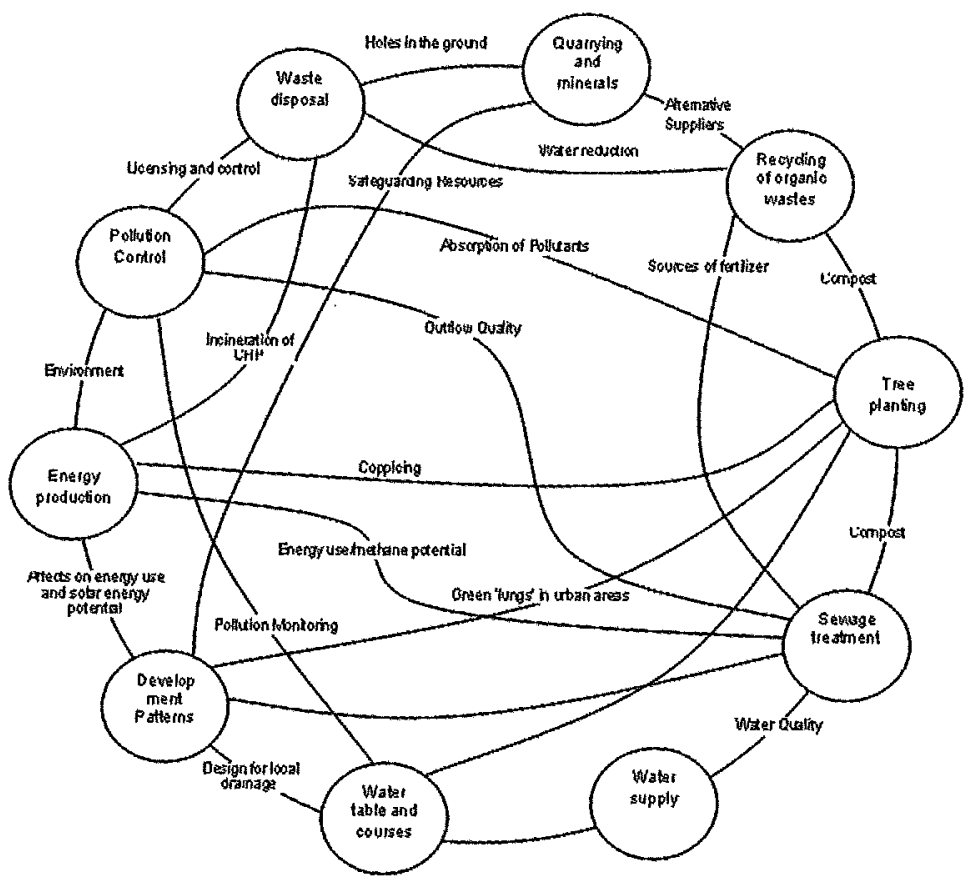

Fig.: Network Analysis of Diverse decision areas

This kind of network analysis of diversified strategic environmental areas of the corporate is reflected through their environment accounting reports. Environmental accounting attempts to provide a qualified data on the total cost incurred on those decision areas (See net work analysis chart) and its positive results achieved through such operations of the company. The 
disclosure of uncoated environmental factors in accounting terms, and the inclusion of these costs, which can then be used as a measure of overall environmental and sustainability welfare.

\section{Conclusion}

It was found that the drive towards enhancing environmental performance increased with the age of the business. The recent trends of corporate houses indicates that apart from the profit maximization they are now interested in protect the planet and the environment and disclose these efforts through environmental accounting reports. Therefore through an indepth explanation of corporate social responsibility and sustainability policy by the corporate houses and its cost-benefit analysis through environmental accounting will be a safe and happy planet for future generations.

\section{References}

AAA Committee on Accounting for Social Performance, 1975 - Accounting Review, Supplement to Vol. XLXI, 1976

American Accounting Association, 'Report of the Committee on Human Resource Accounting', The Accounting Review Supplement to Vol. XLVIII.

American Institute of Certified Public Accountants, The Measurement of Corporate Social Performance (New York: AlCPA, 1977).

Carroll A. B. A Three-dimensional Conceptual Model of Corporate Social Performance, Academy of Management Review, April 1979.

Cochran, P.L, and Wood, R.A, "Corporate Social Responsibility and Financial Performance", Academy of Management Journal, 27, 1984.

Coppock R.M Dierkes, H. Snowball, J.Thomas, "Social Pressure and Business Actions", Paper Presented at Seminar on Corporate Social Accounts, Battelle Seattle Research Center, November 10-11, 1972

D. Blake,W. Fredwick, Social Auditing, (New York: Praeger Publishers, 1976)

Estes Ralph, Corporate Social Accounting, John Willey and Sons, New York, 1976.

Frooman, J., "Socially Irresponsible and Illegal Behavior and Shareholder Wealth: A Recta Analysis of Event Studies", Business and Society, 36, 1997.

Gray, 'Thirty Years of Social Accounting', p. 10 
John J. Corson and George A Steiner, Measuring Business's Social Performance, The Corporate Social Audit (Committee for Economic Development, 1974).

Luis, C. (2005, 'People v. Profits: A False Dichotomy?', University of California, Davis Business Law Journal, Vol. 5/6.

Mobley Sybil, "Challenges of Socio-economic Accounting", Accounting Review.

R.H. Gray, D.L. Owen \& K.T. Maunders, Corporate Social Reporting: Accounting and Accountability (Hemel Hempstead: Prentice Hall, 1987) p. IX.

Shell Sustainability Report 2007.

United Utilities Sustainable development: http://www.unitedutilities.com/ OBH=5349. 